\title{
Distribution and Symbiotic Effectiveness of Rhizobium meliloti in Rangeland Soils of the Intermountain West
}

\author{
W.L. LOWTHER, D.A. JOHNSON, AND M.D. RUMBAUGH
}

\begin{abstract}
Although the interaction between the host plant and its associated Rhizobium is a major factor in determining biological nitrogen fixation, competitive interactions among naturally occurring rhizobial populations can also greatly influence the success of nodulation and subsequent nitrogen fixation. To determine the influence of naturally occurring rhizobial populations on the symbiotic relationship between alfalfa (Medicago sativa $L_{\text {.) }}$ ) and $R$ hizobium meliloti, the distribution of naturalized populations of $R$. meliloti forming effective nodules on alfalifa was determined in representative rangeland soils of the Intermountain West of the United States. A total of 256 sites were sampled within 10 vegetation types where alfalfa is a potential legume for farming, wildlife, or revegetation use. $R$. meliloti capable of forming effective nodules on alfalfa were detected in 4 of the vegetation types (juniper-pinyon woodland, mountain mahogany-oak scrub, sagebrush steppe, and wheatgrass-needlegrass shrubsteppe). However, these rhizobia were detected in only $30 \%$ or less of those sites having a natural vegetative cover. Only where the sagebrush steppe vegetation type had been converted to wheat or alfalfa-grass mixtures were rhizobia detected in the majority of sites (81 and $100 \%$, respectively). Populations of $R$. meliloti within the individual vegetation types ranged from 6 to greater than $1.7 \times 10^{5}$ per $\mathrm{g}$ of soil. Isolates of these naturally occurring $R$. meliloti exhibited a wide range of symbiotic $\mathbf{N}$-fixation effectiveness on alfalfa (cv Spredor 2) with the mean value for the 360 isolates tested being $69 \%$ of the check inoculant strains. Of the isolates tested, $48 \%$ were classified as inferior $\mathbf{N}$-fixers with significantly lower plant yields than control plants inoculated with check rhizobia strains. The relatively limited distribution of detectable populations of $R$. meliloti in the majority of Intermountain West rangeland soils and the high percentage of these that were inferior in $\mathbf{N}$-fixing capability underscores the need to inoculate alfalfa with highly effective and competitive strains of $\boldsymbol{R}$. meliloti.
\end{abstract}

Key Words: Soil bacteria, Medicago sativa, nitrogen fixation, rhizobia, rhizosphere, soil microbiology, symbiosis

Initiation of symbiotic $\mathbf{N}$-fixation in alfalfa (Medicago sativa $\mathbf{L}$.) depends on the presence of strains of Rhizobium meliloti that form effective nodules. In areas devoid of $R$. meliloti, inoculation with an effective strain is essential for nodulation (Burton 1972). Even if present, rhizobia may form ineffective nodules and symbiotic $\mathrm{N}$ fixation can be increased by the introduction of highly effective, competitive strains (Jenkins and Bottomley 1984, Schiffman 1958, Weber and Leggett 1966).

Considerable information exists on the distribution and symbiotic effectiveness of $R$. meliloti in soil (Hely and Brockwell 1962, DeEscuder 1972, Mahler and Wollum 1982, Peterson and Goodding 1941, Sagardoy 1981, Schiffman 1958), but little of these data pertain to rangelands of the Intermountain West of the U.S. The distribution and effectiveness of $R$. meliloti in rangeland ecosys-

\footnotetext{
Authors are agronomist, Invermay Agricultural Research Centre, Research Division, Ministry of Agriculture and Fisheries, Private Bag, Mosgiel, New Zealand; and plant physiologist and research geneticist, respectively, USDA-Agricultural Research Servicc, Forage and Range Research, Utah State Univ., Logan 84322-6300.

Cooperative investigations of the USDA-Agricultural Research Service and the Utah Agricultural Experiment Station, Logan 84322. Approved as paper No. 3266.

Financial assistance for this study was provided by the USDA-ARS and Utah State University Agricultural Experiment Station. The senior author acknowledges the New Zealand Ministry of Agriculture and Fisheries for granting study leave. The capable technical assistance of Cara Cahoon and Howard Skinner is greatly appreciated. Thanks also go to Carolyn Lemon and Betty Wood for their secretarial assistance.

Manuscript accepted 18 December 1986.
}

tems likely would be dependent on a complex of factors including soil type, climate, topography, composition of the vegetation, historical use, and range condition of the particular site. Carlson et al. (1950) stated that benefits from inoculation of alfalfa seed with $R$. meliloti have not been demonstrated in Utah and that soils in Utah apparently are well supplied with effective $R$. meliloti. Rumbaugh and Johnson (1984) reported nodulation of alfalfa in soil samples collected from 26 of the 27 major soil associations in the northern Great Basin area of the western U.S. The rhizobia were not spread uniformly within soil associations because alfalfa nodulated in soil from all sites in only 5 associations.

Isolates of $R$. meliloti vary markedly in thcir symbiotic effectiveness (Hely and Brockwell 1962). $R$. meliloti isolates that are completely ineffective at $\mathrm{N}$-fixation have been found in the $\mathrm{Negev}$ Desert in Israel (Schiffman 1958) and in alfalfa-growing areas in Oregon (Barber 1980, Eardly et al. 1985) and Washington (Weber and Leggett 1966). Rumbaugh and Johnson (1984) reported a wide range of specific nodule activities, as measured by acetylene reduction, suggesting large differences in symbiotic effectiveness of naturally occurring strains of $\boldsymbol{R}$. meliloti on alfalfa in the northern Great Basin.

The objectives of the present study were to: (1) determine the distribution of naturalized populations of $R$. meliloti, capable of forming effective nodules on alfalfa, in soil under the major vegetation types of the Intermountain West of the U.S. and (2) assess the symbiotic $\mathrm{N}$-fixing effectiveness of these naturalized $R$. meliloti on rangeland alfalfa to evaluate the potential for increasing $\mathrm{N}$ fixation through the introduction of highly effective, competitive strains of rhizobia.

\section{Materials and Methods}

\section{Field Sampling}

Sampling was carried out using the general vegetation classification of Küchler (1964) for site descriptions. Ten vegetation types where alfalfa was a potential legume for farming, wildlife, or revegetation use were identified (Table 1). A total of 256 sites were sampled in Idaho, Montana, Nevada, Wyoming, and Utah. The sagebrush steppe vegetation type was subdivided into natural vegetation and conversion to wheat, grass, and alfalfa/grass production.

Individual sampling sites representative of the area were selected, and individual cores of soil $(10 \mathrm{~cm}$ deep and $1.5 \mathrm{~cm}$ diameter) were taken at $1-\mathrm{m}$ intervals along a 5-m transect and bulked in a plastic bag. Sampling corers were sterilized with $90 \%$ ethanol and flaming between sites. Sampling was initiated in late-April at the lower altitudes and completed in August at the higher elevation sites. Altitude of the sampled sites was obtained, and $\mathrm{pH}$ of the soil was determined using a saturated paste.

\section{Distribution of $R$. meliloti}

Soil samples were stored at $4^{\circ} \mathrm{C}$ until processed, which was normally within 7 days of sampling. The soil was thoroughly mixed in the plastic bag and a $10-\mathrm{g}$ subsample taken for $R$. melilot counts. Enumeration was by the "plant infection" method using $\mathrm{N}$-free seedling agar (Vincent 1970). The subsamples of soil from each site were diluted consecutively over the range $10^{-1}$ to $10^{-5}$ in sterile one-fourth strength McKnight's solution (McKnight 1949) and a $1-\mathrm{ml}$ aliquot was used to inoculate each of 2 tubes $(25 \times 150$ $\mathrm{mm}$ ) containing a seedling of 'Spredor 2' alfalfa growing on sloped $\mathrm{N}$-free seedling agar (Jensen 1942). The procedure allowed the 
Table 1. Description of ten vegetation types' sampled in the Intermountain West of the U.S.

\begin{tabular}{|c|c|c|c|c|}
\hline $\begin{array}{l}\text { Küchler } \\
\text { No. }\end{array}$ & Vegetation type & Dominant vegetation & $\begin{array}{l}\text { Altitude } \\
\text { range }(\mathrm{m})\end{array}$ & $\underset{\text { range }}{\mathrm{pH}}$ \\
\hline 11 & Douglas fir forest & Pseudotsuga menziesii & $1650-2340$ & $5.2-7.5$ \\
\hline 14 & Western spruce-fir forest & Abies lasiocarpa, Picea engelmanii & $2020-2440$ & $4.6-6.9$ \\
\hline 21 & Juniper-pinyon woodland & $\begin{array}{l}\text { Juniperus monosperma, J. osteosperma, } \\
\text { Pinus edulis }\end{array}$ & $1200-2110$ & $6.7-8.2$ \\
\hline 31 & Mountain mahogany-oak scrub & Cercocarpus ledifolius, Quercus gambelii & $1400-2000$ & $6.0-7.5$ \\
\hline 32 & Great Basin sagebrush & Artemisia tridentata & $1480-1980$ & $6.1-7.9$ \\
\hline 34 & Saltbush-greasewood & Atriplex confertifolia. Sarcobatus vermiculatus & $1240-1560$ & $7.4-9.5$ \\
\hline $\begin{array}{l}39 \\
45\end{array}$ & $\begin{array}{l}\text { Desert } \\
\text { Alpine meadows and barren }\end{array}$ & $\begin{array}{l}\text { Vegetation largely absent } \\
\text { Agrostis spp., Carex spp., Deschampsia } \\
\text { caespitosa, Festuca viridula, Luzula spicata, } \\
\text { Phleum alpinum, Poa spp., Trisetum spicatum }\end{array}$ & $\begin{array}{l}1240-1510 \\
3200-4000\end{array}$ & $\begin{array}{l}7.7-8.6 \\
4.8-5.5\end{array}$ \\
\hline 49 & Sagebrush steppe & $\begin{array}{l}\text { (a) Agropyron spicatum, Artemisia tridentata } \\
\text { (b) Converted to wheat } \\
\text { (c) Converted to improved grasses } \\
\text { (d) Converted to alfalfa/grass }\end{array}$ & $\begin{array}{l}1330-2580 \\
1330-1550 \\
1350-1720 \\
1350-1510\end{array}$ & $\begin{array}{l}5.2-8.6 \\
6.7-7.8 \\
6.6-8.1 \\
6.1-7.9\end{array}$ \\
\hline 50 & Wheatgrass-needlegrass shrubsteppe & $\begin{array}{l}\text { Agropyron smithii, Artemisia tridentata, Poa arida, } \\
\text { Stipa comata }\end{array}$ & $2060-2510$ & $5.8-7.6$ \\
\hline
\end{tabular}

Based upon the vegetation classification system of Küchler (1964).

detection of a minimum population of $6 \boldsymbol{R}$. meliloti per gram of soil. Estimation of lower numbers by adding more soil to the test tube is not reliable (Thompson and Vincent 1967). Use of the 10-fold dilution series with duplicate aliquots allowed a large number of sites to be sampled (Vincent 1970). After 6 to 8 weeks growth in a shaded glasshouse (see below), the numbers of effective $R$. meliloti in soils were calculated from the number of plants that formed nodules with haemoglobin present (Vincent 1970). Values presented have $95 \%$ fiducial limits of $(x \div) 6.6$.

\section{Symbiotic Effectiveness of $R$. meliloti}

A random sample of 10 pink nodules was obtained from roots at the lowest dilution of soil from sites where seedlings had effective nodules. Sampling at the lowest dilution allows for the possibility of host-plant selection (Masterson and Sherwood 1974). For isolation of rhizobia, nodules were immersed momentarily in $95 \%$ ethanol, sterilized in $3 \%$ calcium hypochlorite for 5 minutes, and rinsed in sterile water (Somasegaran and Hoben 1985). Nodules were crushed in one-fourth strength McKnight's solution, streaked on congo red yeast mannitol (YM) agar (Vincent 1970), and incubated at $25^{\circ} \mathrm{C}$. Single colony isolates were picked, streaked on YM agar slopes, and stored at $4^{\circ} \mathrm{C}$ after incubation. Inoculum suspensions were prepared by streaking isolates on 9-ml slopes of YM agar in $20 \times 150-\mathrm{mm}$ culture tubes, incubating for 7 days at $20^{\circ} \mathrm{C}$, and suspending in $12 \mathrm{ml}$ of one-fourth strength McKnight's solution. An inoculum consisting of $1 \mathrm{ml}$ of suspension was used to inoculate a 'Spredor 2' alfalfa-seedling growing on a $\mathbf{N}$-free seedling agar slope in a $20 \times 150-\mathrm{mm}$ test tube. Each inoculation treatment was replicated 10 times. Isolates were compared with 3 check commercial inoculant strains of $R$. meliloti, including 2 strains, 102F51 and 102F77, obtained from the Nitragin Co., Milwaukee, Wis. ', and strain SU47 obtained from J. Brockwell, CSIRO, Canberra, Australia. In addition, isolates were compared with an uninoculated control and an uninoculated combined-N control that received $3 \mathrm{ml}$ of $18 \mathrm{mmol} \mathrm{KNO}_{3}$ solution $14 \mathrm{~d}$ and $28 \mathrm{~d}$ after sowing (Bottomley and Jenkins 1983). At $28 \mathrm{~d}$ after sowing, each inoculated seedling received $3 \mathrm{ml}$ of sterile, deionized water. Plants were grown in a randomized complete block design in a shaded glasshouse with temperatures maintained at approximately

\footnotetext{
Mention of a trademark name, proprietary product, or vendor does not constitute endorsement by the U.S. Department of Agriculture and does not imply its approval to the exclusion of other products or vendors that may also be suitable.
}

$30^{\circ} \mathrm{C}$ during the day and $15^{\circ} \mathrm{C}$ at night between 17 September and 13 November 1985 . After $49 \mathrm{~d}$, plants were harvested and shoot fresh weights obtained (Vincent 1970). The symbiotic effectiveness of isolates (E) was computed as:

$$
E=\frac{Y_{i}-Y_{n n c}}{Y_{c}-Y_{n n c}} \times 100
$$

where $Y_{i}$ is plant yield of the isolate, $Y_{n n c}$ is plant yield of the nil nitrogen control, and $Y_{c}$ is the mean plant yicld of the 3 check strains.

\section{Results}

$R$. meliloti capable of forming effective nodules on 'Spredor 2' alfalfa were detected in soil taken from 4 out of 10 vegetation types (Table 2). In these 4 vegetation types $R$. meliloti were detected in

Table 2. Distribution of $R$. meliloti in soils of 10 vegetation types sampled in the Intermountain West of the U.S.

\begin{tabular}{|c|c|c|c|}
\hline Vegetation type & $\begin{array}{l}\text { Number of } \\
\text { sites } \\
\text { sampled }\end{array}$ & $\begin{array}{l}\% \text { of sites } \\
\text { with } \\
R . \text { meliloti }\end{array}$ & $\begin{array}{c}\text { Number } R \text {. meliloti } \\
\text { per } \\
\text { g soil }\end{array}$ \\
\hline Douglas fir forest & 28 & 0 & $<6$ \\
\hline $\begin{array}{l}\text { Western spruce-fir } \\
\text { forest }\end{array}$ & 18 & 0 & $<6$ \\
\hline $\begin{array}{l}\text { Juniper-pinyon } \\
\text { woodland }\end{array}$ & 20 & 20 & 6 to $1.7 \times 10^{4}$ \\
\hline $\begin{array}{l}\text { Mountain mahogany- } \\
\text { oak scrub }\end{array}$ & 22 & 18 & 6 to $5.8 \times 10^{4}$ \\
\hline Great Basin sagebrush & 25 & 0 & $<6$ \\
\hline Saltbush-greasewood & 21 & o & $<6$ \\
\hline Desert & 14 & 0 & $<6$ \\
\hline $\begin{array}{l}\text { Alpine meadows and } \\
\text { barren }\end{array}$ & 9 & $\mathbf{0}$ & $<6$ \\
\hline $\begin{array}{l}\text { Sagebrush steppe } \\
\text { (a) Natural vegetation } \\
\text { (b) Wheat } \\
\text { (c) Grass } \\
\text { (d) Alfalfa/grass }\end{array}$ & $\begin{array}{r}50 \\
16 \\
15 \\
3\end{array}$ & $\begin{array}{r}30 \\
81 \\
27 \\
100\end{array}$ & $\begin{array}{c}6 \text { to }>1.7 \times 10^{5} \\
6 \text { to }>1.7 \times 10^{5} \\
6 \text { to } 5.8 \times 10^{4} \\
1.7 \times 10^{4} \text { to }>1.7 \times 10^{5}\end{array}$ \\
\hline $\begin{array}{l}\text { Wheatgrass-needlegrass } \\
\text { shrubsteppe }\end{array}$ & 15 & 13 & 6 to $5.8 \times 10^{4}$ \\
\hline
\end{tabular}

ISites with more than $6 R$. meliloti per $\mathrm{g}$ soil. 
Table 3. Symbiotic effectiveness of isolates of $R$. meliloti from soils of 4 vegetation types sampled in the Intermountain West of the U.S.

\begin{tabular}{|c|c|c|c|c|c|c|}
\hline \multirow[b]{2}{*}{ Vegetation type } & \multirow[b]{2}{*}{ No. of isolates } & \multicolumn{2}{|c|}{ Effectiveness (\%) } & \multicolumn{3}{|c|}{ Percent isolates classed as ${ }^{1}$} \\
\hline & & Mean & Range & Superior & Effective & Inferior \\
\hline Juniper-pinyon woodland & 20 & 62 & $21-128$ & 0 & 35 & 65 \\
\hline Mountain mahogany-oak scrub & 30 & 68 & $25-124$ & 0 & 43 & 57 \\
\hline $\begin{array}{l}\text { Sagebrush steppe } \\
\text { (a) Natural vegetation } \\
\text { (b) Wheat } \\
\text { (c) Grass } \\
\text { (d) Alfalfa/grass } \\
\text { Mean }\end{array}$ & $\begin{array}{r}130 \\
130 \\
20 \\
20\end{array}$ & $\begin{array}{l}71 \\
69 \\
70 \\
66\end{array}$ & $\begin{array}{r}2-132 \\
0-118 \\
32-105 \\
41-99\end{array}$ & $\begin{array}{l}1 \\
0 \\
0 \\
0 \\
1\end{array}$ & $\begin{array}{l}56 \\
52 \\
55 \\
50 \\
54\end{array}$ & $\begin{array}{l}43 \\
48 \\
45 \\
50 \\
46\end{array}$ \\
\hline $\begin{array}{l}\text { Wheatgrass-needlegrass } \\
\text { shrubsteppe }\end{array}$ & 10 & 63 & 13-139 & 10 & 30 & 60 \\
\hline Overall Mean & & & & 1 & 51 & 48 \\
\hline
\end{tabular}

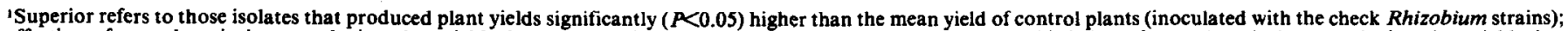

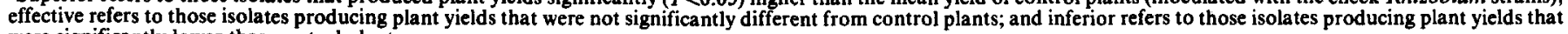
were significantly lower than control plants.

only $30 \%$ or fewer of the sampling sites with a natural vegetation cover. Only where the sagebrush steppe vegetation type had been converted to wheat or alfalfa/grass were $R$. meliloti detected in the majority of sites ( 81 and $100 \%$, respectively). $R$. meliloti populations exceeded $1.7 \times 10^{4}$ per $g$ of soil on sagebrush steppe sites that had been converted to alfalfa/grass (Table 2). Populations on all of the other sites with detectable levels of $\boldsymbol{R}$. meliloti varied from a mean of 6 to greater than $1.7 \times 10^{5}$ per $\mathrm{g}$ of soil.

Unlike the limited distribution of effective nodules on alfalfa, white nodule-like structures were more widespread on seedlings. However, in contrast to effective nodulation where 'skip' tubes (i.e., tubes where plants fail to nodulate at low dilutions but nodulate at higher dilutions; Thompson and Vincent 1967) were virtually absent, these white 'nodules' often occurred on seedlings at $10^{-4}$ or $10^{-5}$ dilutions but not at the lower dilutions. Many could be identified as 'pseudo-nodules'(Gibson 1980); however, others were similar in size and shape to the effective nodules, but haemoglobin was absent. Bacteria with similar colony characteristics to rhizobia were isolated from 20 of these white nodules. These isolates formed white 'nodules' on only $20-60 \%$ of seedlings when reinoculated onto alfalfa. Plants with these white 'nodules' showed no evidence of symbiotic $\mathrm{N}$-fixation.

There was a wide range of symbiotic $\mathbf{N}$-fixing effectiveness of individual isolates of $\boldsymbol{R}$. meliloti from the rangeland soils (Table 3). No significant differences $(P<0.05)$ in mean effectiveness of the isolates were found among the various vegetation types as evaluated by homogeneity Chi-square statistical procedures. The sites within each vegetation type, except where the sagebrush steppe type had been converted to alfalfa/grass, were not homogenous with respect to the frequency of inferior isolates as indicated by Chi-square analysis $(P<0.05)$. Of the 360 isolates tested, only 2 isolates produced higher plant yields than the mean of the 3 check inoculant strains, while $51 \%$ produced similar yields and $48 \%$ were classed as inferior. Of the isolates classed as inferior, $2 \%$ produced symbiotically derived plant growth that was not significantly different from the yield of uninoculated control plants (data not shown).

\section{Discussion}

The limited distribution of effective strains of $R$. meliloti in soils of the Intermountain West is similar to that reported by Peterson and Gooding (1941) in Nebraska, However, it is not consistent with the widespread distribution of $R$. meliloti in soils of the northern Great Basin area of Utah and Idaho reported by Rumbaugh and Johnson (1984). The discrepancy probably is related to the different techniques used to assess the presence of $\boldsymbol{R}$. meliloti. Rumbaugh and Johnson (1984) grew alfalfa in a glasshouse in open containers holding soils representing the major soil associations, and $R$. melilot $i$ was considered to be present if alfalfa nodulated. Studies in the same glasshouse area used in their survey indicated that there was a high potential for rapid and extensive contamination by $R$. meliloti. Consequently, contamination of the soils in the open containers by dust-borne $R$. meliloti may have resulted in an overestimation of the distribution of $R$. meliloti.

Another possible reason for the discrepancy between the results of Rumbaugh and Johnson (1984) and those obtained in the present study may have been the categories of nodulation recorded. In the present study, only nodules having haemoglobin were recorded, while Rumbaugh and Johnson did not distinguish between effective and white 'nodules'. The need to distinguish between true nodules and 'false' or 'pseudo-nodules' has been documented (Vin cent 1970, Gibson 1980). In the present study the white 'nodules' that occurred sporadically are considered to be 'pseduo-nodules', possibly due to infection of the alfalfa root by heterologous rhizobia. For example, the indigenous rhizobia that nodulate rangeland Astragalus species, which occur widely in the vegetation types sampled, can form 'nodules' on alfalfa (Wilson and Chin 1947). The sporadic occurrence of these white 'nodules' is not attributed to nodulation by ineffective $R$. meliloti because the bacteria isolated could not consistently renodulate alfalfa. Weber and Leggett (1966) attributed alfalfa sickness in Washington State to the presence of ineffective rhizobia which formed a few malformed, nonpigmented nodules. Some of the isolates from these nodules failed to form nodules when reinoculated onto alfalfa, suggesting that 'pseudo-nodulation' may have occurred. Further investigation appears warranted concerning the effect of this 'pseudo-nodulation' on symbiotic $\mathrm{N}$-fixation of alfalfa plants inoculated with highly effective strains of $R$. meliloti

The widespread occurrence of very low populations of effective strains of $R$. meliloticannot be discounted from the present survey because a minimum population of 6 rhizobia $\mathrm{g}^{-1}$ of soil was detectable with the technique used. Under the favorable glasshouse conditions used by Rumbaugh and Johnson (1984) populations of less than 6 rhizobia $\mathrm{g}^{-1}$ of soil would be expected to be sufficient to ensure nodulation.

The limited distribution of effective $R$. melilot in rangeland soils from areas with natural vegetation cover indicates that spread by natural means (e.g. in windborn dust) occurs slowly. This slow rate of dispersion apparently occurs even though sources of $R$. meliloti are widespread due to the extensive use of irrigated and dryland alfalfa, particularly in the sagebrush and juniper-pinyon areas. In contrast, the high percentage of wheat fields with $R$. meliloti suggests tillage results in a more rapid and uniform spread, although improved survival in wheat field soil through changes in 
soil physical/chemical properties cannot be discounted.

Vincent (1974) reported that $\boldsymbol{R}$. meliloti failed to establish in pasture soil because of susceptibility to low $\mathrm{pH}$. In our present study, there was only 1 vegetation type (alpine meadow) in which the $\mathrm{pH}$ of all sites sampled was less than 5.5 to 6.0, the range shown to restrict multiplication of $R$. meliloti in soil (Rice et al. 1977). Consequently, the restricted distribution of $R$. meliloti in rangeland soils apparently cannot be attributed to soil acidity. In our present study, soil samples were taken to a depth of $10 \mathrm{~cm}$, a zone considered important for initial nodulation of alfalfa seedlings. However, spread of $\boldsymbol{R}$. meliloti in these rangeland soils may be limited by failure of rhizobia to survive in the surface layer due to susceptibility to high temperature (Danso and Alexander 1974) and desiccation (Van Rensburg and Strijdom 1980).

Because of the problems with survival of $R$. meliloti in soils, inoculation of alfalfa is normally recommended unless the area to be sown has recently been cultivated out of alfalfa (Vincent 1974). In contrast, Carlson et al. (1950) claimed that benefits from inoculation have not been demonstrated in Utah and that the soils generally appear to be well supplied with rhizobia. The results of the present study indicate the general need for inoculation on rangeland sites. Inoculation is essential for nodulation in the absence of soil rhizobia, but the need for inoculation on soils with low populations of rhizobia is not as clear. However, even if the rangeland soils of the Intermountain West do harbour low populations of $R$. meliloti (i.e., less than 6 rhizobia $\mathrm{g}^{-1}$ of soil), inoculation is still recommended to ensure rapid nodulation of alfalfa. This may be particularly critical under rangeland conditions where establishment is required before the onset of dry summer conditions.

Our findings concerning the wide range of $\mathrm{N}$-fixing effectiveness of the isolates within sites is in agreement with previous studies with $R$. meliloti (Barber 1980, Bottomley and Jenkins 1983, Jenkins and Bottomley 1984). Because cultivars of alfalfa can vary in their response to specific strains of rhizobia (Burton and Wilson 1939), a commercially available cultivar (Spredor 2) developed for pastures was used as the symbiotic host in the present study. The prevalence of isolates whose $\mathrm{N}$-fixing ability was inferior to the check inoculant strains indicates that uninoculated alfalfa planted on these rangeland sites may have a reduced potential for symbiotic $\mathbf{N}$-fixation. Hardarson et al. (1981) demonstrated a significant positive correlation between the percentage of nodules produced by an effective rhizobia strain and the dry matter of alfalfa plants. Further research is required under rangeland conditions to determine the agronomic significance of the presence of inferior rhizobia strains and the possibility that $\mathrm{N}$-fixation can be increased by inoculating seeds with effective and competitive rhizobial strains.

\section{References}

Barber, L.E. 1980. Enumeration, effectiveness, and $\mathrm{pH}$ resistance of Rhizobium meliloti populations in Oregon soils. Soil Sci. Soc. Amer. J. 44:537-539.

Bottomley, P.J., and M.B. Jenkins. 1983. Some characteristics of Rhizobium meliloti isolates from alfalfa fields in Oregon. Soil Sci. Soc. Amer. J. 47:1153-1157.

Burton, J.C. 1972. Nodulation and symbiotic nitrogen fixation. p. 229-246. In: C.H. Hanson (ed.) Alfalfa Science and Technology. American Society of Agronomy Monograph 15. Amer. Soc. of Agron., Inc., Madison, Wisconsin.

Burton, J.C, and P.W. Wilson. 1939. Host plant specificity among the Medicago in association with root-nodule bacteria. Soil Sci. 47:293-303.

Carlson, J.W., R.J. Evans, M.M. Pederson, and G.L. Stoker. 1950. Growing alfalfa for seed in Utah. Utah Agr. Exp. Sta. Circ. 125. Utah State Univ., Logan.
Danson, S.K.A., and M. Alexander. 1974. Survival of 2 strains of Rhizobium in soil. Soil Sci. Soc. Amer. Proc. 38:86-89.

DeEscuder, A.M.Q. 1972. A survey of rhizobia in farm soils at Wye College, Kent. J. Appl. Bacteriol. 35:109-118.

Eardly, B.B., D.B. Hannaway, and P.J. Bottomley. 1985. Nitrogen nutrition and yield of seedling alfalfa as affected by ammonium nitrate fertilization. Agron. J. 77:57-62.

Gibson, A.H. 1980. Methods for legumes in glasshouse and controlled environmental cabinets. p. 139-184. In: F.J. Bergersen (ed.) Methods for evaluating biological nitrogen fixation. John Wiley \& Sons Ltd., New York.

Hardarson, G., G.H. Heichel, C.P. Vance, and D.K. Barnes. 1981. Evaluation of alfalfa and Rhizobium meliloti for compatibility in nodulation and nodule effectiveness. Crop Sci. 21:562-567.

Hely, F.W., and J. Brockwell. 1962. An exploratory survey of the ecology of Rhizobium meliloti in inland New South Wales and Queensland. Aust. J. Agr. Res. 13:864-879.

Jenkins, M.B., and P.J. Bottomley. 1984. Seasonal response of uninoculated alfalfa to $\mathbf{N}$ fertilizer: soil $\mathbf{N}$, nodule turnover, and symbiotic effectiveness of Rhizobium meliloti. Agron. J. 76:959-963.

Jensen, H.L. 1942. Nitrogen fixation in leguminous plants. 1. General characteristics of root-nodule bacteria isolated from species of Medicago and Trifolium in Australia. Proc. Linn. Soc. N.S.W. 66:98-108.

Kiichler, A.W. 1964. Potential natural vegetation of the conterminous United States. American Geographical Society Special Publication No. 36. American Geographical Society, New York.

Mahler, R.L., and A.G. Wollum. 1982. Seasonal variation of Rhizobium meliloti in alfalfa hay and cultivated fields in North Carolina. Agron. J. $74: 428-431$

Masterson, C.L., and M.T. Sherwood. 1974. Selection of Rhizobium trifolii strains by white and subterranean clovers. Irish J. Agr. Res. 13:91-99.

McKnight, T. 1949. Efficiency of isolates of Rhizobium in the cowpea group, with proposed additions to this group. Queensland J. Agr. Sci. 6:61-76.

Peterson, H.B., and T.H. Goodding. 1941. The geographic distribution of Azotobacter and Rhizobium meliloti in Nebraska soils in relation to certain environmental factors. Nebraska Agr. Exp. Sta. Bull. 121. Univ. Nebraska, Lincoln.

Rice, W.A., D.C. Penney, and M. Nyborg. 1977. Effects of soil acidity on rhizobia numbers, nodulation and nitrogen fixation by alfalfa and red clover. Can. J. Soil Sci. 57:197-203.

Rumbaugh, M.D., and D.A. Johnson. 1984. Nodulation and acetylene reduction by 2 legumes with rhizobia indigenous to northern Great Basin soils. Great Basin Natur. 44:151-158.

Sagardoy, M.A. 1981. Number and distribution of Rhizobium meliloti and other microbial populations in soils. Ann. Edaf. Agrobiol. 40:889-895.

Schiffmann, J. 1958. Ineffectiveness of alfalfa nodule bacteria ( $R$ hizobium meliloti) in Negev soils and improvement by soil inoculation. Min. Agr. Israel Agr. Res. Sta. Rehovet 9:57-67.

Somasegaran, P., and H.J. Hoben. 1985. Methods in legume-rhizobium technology. NIFTAL, University of Hawaii, Paia.

Thompson, J.A., and J.M. Vincent. 1967. Methods of detection and estimation of rhizobia in soil. Plant Soil 26:72-84.

Van Rensburg, H.J., and B.W. Strijdom. 1980. Survival of fast- and slow-growing Rhizobium spp. under conditions of relatively mild desiccation. Soil Biol. Biochem. 12:353-356.

Vincent, J.M. 1970. A manual for the practical study of root-nodule bacteria. IBP Handb. No. 15. Blackwell Scientific Publ., Oxford, England.

Vincent, J.M. 1974. Root-nodule symbiosis with Rhizobium. p. 265-341. In: A. Quispel (ed.) The biology of nitrogen fixation. North-Holland Publ. Company, Amsterdam.

Weber, D.F., and G.E. Leggett. 1966. Relation of rhizobia to alfalfa sickness in eastern Washington. USDA-ARS Res. Rep. 41-117.

Wilson, J.K., and C.H. Chin. 1947. Symbiotic studies with isolates from nodules of species of Astragalus. Soil Sci. 63:119-127. 